\title{
Tratamiento quirúrgico de hipertrofia maseterina: Reporte de un caso con seguimiento de seis años
}

\author{
Surgical Treatment for Masseteric Hypertrophy: \\ Case Report with Six-year Follow-up
}

N. Yanine ${ }^{1}$, I. Araya 1 , M. Cornejo ${ }^{2,3}$, J. Villanueva ${ }^{1,2}$

Resumen: La hipertrofia maseterina es una condición benigna que puede manifestarse en forma bilateral o unilateral. Presenta como principal problema el componente estético. Se han planteado diversos tratamientos, siendo la alternativa quirúrgica la más radical y predecible. Se presenta el caso de una adolescente de 15 años que presentó hipertrofia maseterina unilateral, la cual fue tratada en forma quirúrgica y fue controlada durante 6 años sin recidivas.

Palabras clave: Hipertofia maseterina; Asimetría facial; Masetero.

Recibido: 24.09.2008

Aceptado: 25.08.2009
Abstract: Masseteric hypertrophy is a benign condition that can be appear in an asymmetric or symmetric form. Aesthetics is the main problem. Many treatments have been proposed, the surgical alternative is the most predictable and radical. We present the case of a 15 year-old girl with asymmetric masseteric hypertrophy who is surgically treated and then monitored for 6 years without recurrences.

Key words: Masseteric hypertrophy; Asymmetric face; Masseter.

\footnotetext{
1 Departamento de Cirugía y Traumatología Máxilo Facial. Facultad de Odontología. Universidad de Chile. Santiago, Chile.

2 Servicio de Cirugía Máxilo Facial. Hospital Clínico San Borja Arriarán. Chile.

3 Departamento de Radiología. Facultad de Odontología. Universidad de Chile. Chile.
}

\section{Correspondencia:}

Dr. Nicolás Yanine Montaner

Departamento de Cirugía y Traumatología Máxilofacial

Facultad de Odontología, Universidad de Chile.

Olivos 973, Independencia, Santiago, Chile.

Email: nyanine@gmail.com 


\section{Introducción}

La hipertrofia maseterina es una condición benigna que se puede presentar uni o bilateralmente de forma asintomática, a la cual se le ha asignado una etiología poco clara, pero que se le ha atribuido a las condiciones funcionales del individuo. En la mayoría de los casos, el motivo de consulta es estético, en donde además del aumento de volumen en la región involucrada, se puede acompañar de exostosis del ángulo mandibular. Generalmente se presenta en pacientes jóvenes en que el bruxismo, uso de goma de mascar y condiciones de stress benefician una sobreactividad maseterina. También

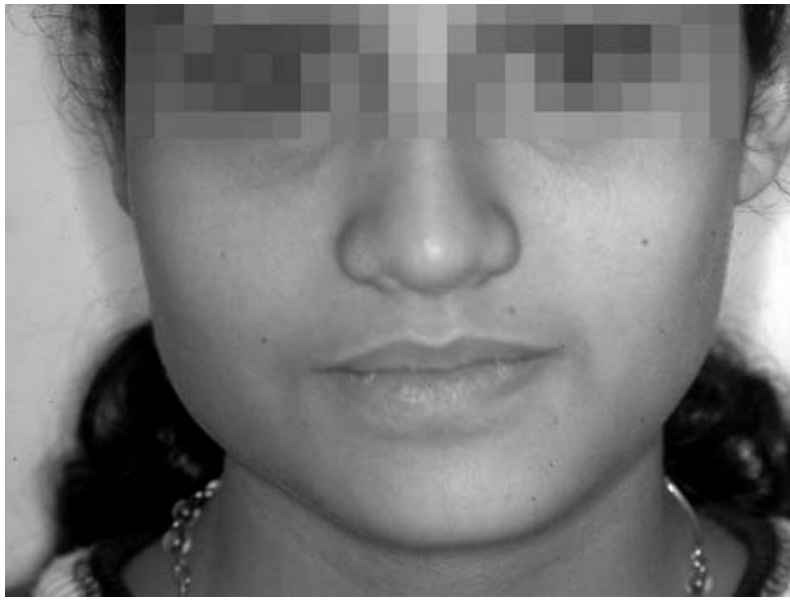

Figura 1. Aumento volumen ángulo mandibular derecho. Figure 1. Increase in the right angle region.

\section{Introduction}

Masseteric hypertrophy is a benign condition that can be asymptomatically appear in an asymmetric or symmetric form. This condition has an unclear etiology and comes from functional conditions of the individual. In most cases, the consult is because aesthetic reasons, due to the increased volume of the involved region that can also be accompanied by a mandible angle exostosis. This condition is generally found in young patients who ha sido descrita su relación con el uso de anabólicos. ${ }^{1}$ Su diagnóstico puede ser confundido con otras patologías como parotiditis, tumores benignos musculares o lesiones vasculares que provocan aumento de volumen en esa región, por lo que un correcto y exhaustivo examen clínico es necesario. ${ }^{2}$ Se han propuesto una diversidad de tratamientos que van desde medidas poco invasivas como el uso de relajantes musculares, planos de relajación y toxina botulínica hasta tratamientos más drásticos como la cirugía. ${ }^{2}$

Se presenta el caso de una paciente con hipertrofia maseterina unilateral que es tratada en forma quirúrgica mediante la resección del ángulo mandibular por vía extraoral.

\section{Caso clínico}

Se presenta en el Servicio de Cirugía Máxilofacial del Complejo Hospitalario San Borja Arriarán un paciente de sexo femenino de 15 años de edad consultando por asimetría facial derecha, indolora, que ha evolucionado en el tiempo en forma progresiva sin ninguna otra sintomatología.

En la entrevista, la paciente no refiere antecedentes mórbidos ni quirúrgicos. Tampoco refiere el uso de algún fármaco en forma usual ni alergias. Ningún tipo de parafunción es pesquisada.

Al examen extraoral se observa un aumento de volumen en la región del ángulo mandibular derecho de límites poco definidos (Fig. 1). A la palpación es de consistencia firme, indoloro y no presenta signos inflamatorios ni compromiso ganglionar submandibular o cervical. En el examen de ATM no se detectan signos ni síntomas patológicos.

Al examen intraoral no se observa nada relevante en relación a los tejidos blandos, dentarios y oclusión. La secreción salival se presentaba normal, especialmente en relación a los conductos de Stenon.

Se solicitó una radiografía panorámica, observándose un ángulo mandibular derecho mucho más marcado (Fig. 2). En la radiografía lateral de cráneo se observó doble contorno mandibular y en la teleradiografía frontal se observó que el sector mandibular derecho presenta un mayor desarrollo, no repercutiendo en el plano oclusal. Además, se realizó una escintigrafía ósea para descartar una hiperplasia condilar y una electromiografía.

El diagnóstico fue de hipertrofia maseterina unilateral derecha por lo que se decide la resección del ángulo mandibular derecho por vía extraoral. use a night guard or chewing gum and are under stress which can cause masseteric hyperactivity. It has also been related with the use of anabolic substances.

Its diagnosis can be confused with other pathologies such as: parotiditis, benign muscle tumor or vascular lesions causing a volume increase of this region, so a comprehensive clinical examination is needed. ${ }^{2}$ Many treatments have been proposed from less invasive measures like muscle relaxers, mouth guards and botulinic toxins to more drastic measures like surgery. The proposed treatment has suggested low invasive measures such as muscle relaxants, mouth guards, botulinic toxin and surgery. ${ }^{2}$

The case of a patient with asymmetric masseteric hypertrophy surgically treated by extra oral resection of mandible angle is presented.

\section{Clinical case}

At the Unit of Maxillofacial Surgery at San Borja Arriarán Hospital, a 15 year old female patient went to the doctor because of a painless right facial asymmetry progressively appearing without other symptoms.

During the consultation, the patient does not report a morbid or surgical background, use of pharmaceuticals, allergies or other type of malfunctioning.

During the extra oral examination, an increase in the right angle region is observed, with unclear limits, hard and painless at palpation (Fig. 1). During palpation we could not observe inflammatory signs, or compromise of the sub mandible or cervical gland. The TMJ (Temporomandibular Joint) exam did not show pathological signs or symptoms.

The intra oral examination does not show any significant signs regarding soft tissues, denture or occlusion. Salivary secretion is normal, particularly in terms of the Stemson's ducts.

The panoramic $x$-ray showed a more marked right 
Bajo anestesia general, se realiza un acceso subángulo-mandibular derecho hasta exponer el ángulo ipsilateral. Se realiza la resección de dicho ángulo y de una porción del músculo masetero. Se realizó una biopsia del músculo extraído, cuyo informe no reveló ninguna condición patológica de los tejidos.

El paciente se controló inmediatamente después de la intervención no presentando complicaciones. En el control realizado luego de 6 años, la paciente se encuentra en buenas condiciones no presentando recidivas (Fig. 3).

\section{Discusión}

La hipertrofia maseterina ha sido descrita como una condición benigna que se puede presentar en forma uni o bilateral cuya etiología no ha sido bien establecida. Se han planteado diversos factores adquiridos que pudiesen favorecer su aparición. Dicho aumento de volumen muscular puede o no presentarse con exostosis en la región del ángulo madibular, lo cual sí se manifestó en este caso, lo que se explicaría, como una respuesta funcional de los tejidos óseos frente a un músculo de mayor calibre. No se trata de un aumento de la actividad electromiográfica del músculo sino que la fuerza de dicho músculo es mayor, como lo demostró Roncevic, ${ }^{3}$ quien observó que en casos de asimetría, la actividad electromiográfica era igual entre ambos músculos. Estos resultados fueron similares a los encontrados por nosotros en la electromiografía.

El diagnóstico puede ser confundido con otras patologías, ${ }^{3}$ por lo que una buena entrevista y un correcto examen clínico son fundamentales. Exámenes complementarios de gran ayuda son el TAC y la resonancia nuclear magnética. ${ }^{4}$

En relación al tratamiento, existen diversas publicaciones que proponen la resección de la exostosis angular (en caso de presentarse) con miotomía parcial del masetero, independiente del acceso elegido, ${ }^{5-10}$ en donde los resultados son satisfactorios, no existiendo reportes de recidiva, como lo reafirma nuestro caso luego de 6 años de realizada la intervención. Producto de la exéresis de una porción de músculo masetero, además de la pérdida de masa muscular, una parte de las fibras que formaban parte de dicha porción se atrofian, provocando el resultado esperado..$^{6-8}$ Lo anterior es interesante, puesto que si la causa etiológica no se elimina, se tendría que esperar una recidiva de la condición, pero debido a dicha atrofia, esto no ocurre. Lo, Mardini y Chen ${ }^{11}$ midieron la pérdida de volumen de los músculos masticatorios (pterigoideo interno, externo y masetero) sólo al realizar la resección de los ángulos mandibulares con un seguimiento de 4 años y medio. Observaron que los cambios volumétricos no eran importantes pero que bastaban para determinar una mejoría estética. Incluso hallaron que el pterigoideo externo presentaba un aumento en mandible angle (Fig. 2). The skull lateral $x$-ray showed a double mandible boundary and the frontal tele-x-ray showed that the mandible right area had a greater development without affecting the occlusal plane. An osseous scintigraphy and an electromyography were performed in order to eliminate the possibility of condyle hyperplasia. The diagnosis was a right asymmetric masseteric hypertrophy, which led to an extra oral resection of the right mandible angle.

Under general anesthesia, a mandible sub angle access is made to expose the ipsilateral angle. This angle and part of the masseteric muscle are resectioned. Biopsy of the resectioned muscle did not show any pathological condition of tissues.

The patient was immediately monitored after the surgery without complications. The patient was examined 6 years later and was in good condition without recurrences (Fig. 3).

\section{Discussion}

The masseteric hypertrophy has been described as a benign condition that can be presented in an asymmetric or symmetric form. Its etiology has not been well defined. Several acquired conditions have been proposed as the cause of appearance. The muscle volume increase can appear together with an exosthosis in the mandible angle region. Our patient had this condition which can be explained as the soft tissues' response to this high caliber muscle. This condition does not mean an increase in the muscle electromyographic activity. Roncevic ${ }^{3}$ has demonstrated that in asymmetry cases the electromyographic activity is equal in both muscles. This condition is not an increase in the electromyographic activity of muscle but the force of such muscle is greater. Results were similar to those found in our electromyography.

Diagnosis can be confused with other pathologies, ${ }^{2}$ so a good interview and a clinical examination are crucial. The CAT (Computed Axial Tomography) and the nuclear magnetic resonance 4 are very useful.

Regarding treatment, there are several documents that 
su volumen por un mecanismo compensatorio. La biopsia del músculo extraído mostró fibras musculares totalmente normales, sin ningún grado de hipertrofia o anomalía, lo que hace cuestionarse si esta condición realmente se trata de un tejido hipertrófico o de un crecimiento muscular de otra índole. Podría plantearse que existirín casos en que los estímulos funcionales provocan el crecimiento (reclutamiento de fibras musculares) y que otros serían debido a anomalías genéticas, puesto que en nuestro caso, el paciente no presentaba antecedentes de alguna predisposición a desarrollar una hipertrofia maseterina. Andante ${ }^{8}$ propone que sólo sería una condición genética, puesto que encontró fibras normales en las biopsias y postula como "hiperplasia maseterina" una definición más apropiada.

Un aspecto importante que se tiene que tomar en cuenta en la técnica del procedimiento son las complicaciones al realizar la resección angular, como un daño al nervio dentario inferior ${ }^{12} \mathrm{o}$ una hemorragia a partir de la arteria maseterina. ${ }^{13}$ En nuestro caso, no tuvimos dichas complicaciones, dado el acceso elegido y a la planificación a través de cefalometrías para determinar la cantidad de ángulo a extirpar.

Una alternativa que recientemente ha surgido es el uso de la toxina botulínica, que impide la acción de terminales colinérgicos, bloqueando impulsos presinápticos neuromusculares. Luego, nuevas inervaciones son generadas, recuperándose la actividad pre-sináptica. Debido a que por un tiempo existió la imposibilidad por activar al músculo, el hábito que en un principio causó la hipertrofia normalmente es detenido y el resultado inicial se mantiene. ${ }^{14}$

La literatura revisada no entrega una etiología clara sobre dicha patología. Si bien su pronóstico es bueno y los resultados del tratamiento quirúrgico estables en el tiempo, son necesarios más estudios al respecto para comprender más profundamente su naturaleza.

\section{Bibliografía}

1. Skoura C, Mourouzis C, Saranteas T, Chatzigianni E, Tesseromatis C. Masseteric hypertrophy associated with administration of anabolic steroids and unilateral mastication: a case report. Oral Surg Oral Med Oral Pathol Oral Radiol Endod 2001;92:515-8.

2. Mandel L., Surattanont F. Bilateral parotid swelling: a review. Oral Surg Oral Med Oral Pathol Oral Radiol Endod 2002;93:221-37.

3. Roncevic R. Masseter muscle hyperthrophy. Aethiology and therapy. J Maxillofac Surg 1986;14:344-8.

4. Seltzer S, Wang A. Modern imaging of the masseter muscle: normal anatomy and pathosis on CT and MRI. Oral Surg Oral Med Oral Pathol 1987;63:622-9.

5. Nishida M.,lizuka T. Intraoral removal of the enlarged mandibular angle associated with masseteric hyperthrophy. J Oral Maxillofac Surg 1995;53:1476-9.

6. Wood G. Masseteric hyperthrophy and surgical correction. Br Dent J 1982;152:416-7.

7. Chee LF, Fei YJ. Surgical correction of masseter muscle hyperthrophy by an intraoral approach. J Oral Maxillofac Surg 1989;47:883-5.

8. Addante R. Masseter muscle hyperthrophy: report of case and literature review. J Oral Maxillofac Surg 1994;52:1199-2.

9. Yooho L, Jun Ho K. Mandibular contouring: a surgical technique for the asymmetrical lower face. Plast Recons Surg 1999;104:1165-1.

10. Deguchi M, lio Y, Kobayashi K, Shirakabe T. Angle-splitting ostectomy for reducing the width of the lower face. Plast Recons Surg 1997;99:1831-9.

11. Lo L, Mardini S, Chen Y. Volumetric change of the muscles of mastication following resection of mandibular angles. A long term follow up. Ann Plast Surg 2005;54:615-1.

12. Lo LJ, Wong FW, Chen YR. The position of the inferior alveolar nerve at the mandibular angle: an anatomic consideration for aesthetic mandibular angle reduction. Ann Plast Surg 2004;53:50-5.

13. Hwang K, Kim Y, Chung I, Lee S. Deep middle masseteric artery attributed to hemorrhage in resection of masseter muscle and mandibular angle. / Craniofac Surg 2001;12:381-5.

14. Mandel L, Tharakan M. Treatment of unilateral masseteric hyperthrophy with botulinum toxin: a case report. J Oral Maxillofac Surg 1999;57:1017-9. suggest the angle exosthosis resection (when it is appears) with partial masseter myotomy without considering the chosen access. 5.10 Results are satisfactory and without recurrences, as showed in our case six years after surgery.

The partial excision of the masseter muscle resulted in a loss of muscle mass and part of the fibers surrounding this portion suffered atrophy causing the expected result. 6-8 Recurrences can be expected if the etiological cause is not eliminated, but it will not happen because of atrophy. Lo, Mardini and Chen," after $a 4$ and a half year follow-up, measured the volume loss of masticatory muscles (internal, external pterygoid nerves and masseter) at the resection of mandible angles. They observed that volume changes were not significant but they were enough to determine an aesthetic improvement. They also found that the external pteryoid never had a volume increase because of a compensatory mechanism.

Muscle biopsy of the removed section showed completely normal muscle fibers, without hypertrophy or anomalies. This leads us to question if it is caused by hypertrophic tissues or by a muscle increase caused other factors. It's possible that in some cases the functional stimuli cause the volume increase (muscle fiber recruitment) and in other cases it is caused by genetic anomalies. This patient did not have any background involving a predisposition to develop a masseteric hypertrophy. Addante $e^{8}$ suggests that the masseteric hypertrophy constitute only a genetic condition since he found normal fibers in biopsies and suggests the "masseteric hyperplasia" as the more appropriate definition.

It is important to consider complications when carrying out the angular resection for example lower dentary nerve damage ${ }^{12}$ or masseteric artery hemorrhage..$^{13}$ In this case, these complications were not and issue because of the access and cephalometries chosen to determine the quantity of angle to be extirpated.

At present, botulinic toxin is a new alternative that prevents the action of cholinergic terminals blocking the neuromuscular presynaptic impulses. Then new innervations are generated recovering the presynaptic activity. The habit that caused the hypertrophy is stopped because the muscle could not be activated during a period, thus maintaining the initial result. ${ }^{14}$

In our opinion, literature regarding the etiology on this pathology is unclear. Although the prognostic is good and surgical treatment results are steady in time, more studies are required for a deeper understanding of its nature. 